\title{
COVID-19 and the Health Industry: A Test of Market Efficiency
}

\author{
Frank W. Bacon \\ Longwood University
}

\author{
William N. Howell \\ Longwood University
}

\begin{abstract}
The World Health Organization declared the COVID-19 coronavirus outbreak as a global pandemic on March 11, 2020. How does the market react to a global pandemic announcement? How efficient is the market? The purpose of this study is to test for semi-strong form market efficiency. Will the healthcare industry show excess gains? A link between the market and pandemics can be inferred but has not been heavily studied. In the efficient market hypothesis, Fama (1970) proposes that in semi-strong form market efficiency, all public information is factored into the market and no investor can achieve a risk-adjusted, above normal return. To study this relationship, S\&P 500 data on 10 healthcare firms was collected for several days surrounding the announcement and standard event study methodology from finance literature was used. Evidence here supports the expected positive signal associated with the sample firms and pandemic announcement. Likewise, the results support the semi-strong form efficient market hypothesis and suggests the possibility of trading on this information up to 24 days before the announcement.
\end{abstract}

Keywords: market efficiency, Covid-19 pandemic, announcement

\section{INTRODUCTION}

The World Health Organization (WHO), on Wednesday March 11, 2020, declared the rapidly spreading coronavirus outbreak a global pandemic, acknowledging that the virus would likely spread to all countries on the globe. How fast does the stock market react to publicly announced information? According to Fama (1970), market efficiency can take on three forms: weak form efficiency, semi-strong form efficiency, and strong form efficiency. According to the efficient market hypothesis, the stock market should immediately respond to public announcement of a pandemic making it impossible for an investor to "beat the market" or to make an above normal risk adjusted return by acting on such information. This study investigates whether an investor can achieve an above normal return by capitalizing on the public announcement of the coronavirus pandemic (Bacon, 2008, 2017, 2018, and 2020).

SARS-CoV-2 is the name of the virus that causes the disease commonly known as coronavirus (COVID-19). As of June 2021, the United States reported 33.5 million covid-19 cases with 600,000 deaths. Worldwide there have been 180 million cases with more than 3.9 million deaths worldwide (WHO, 2020). The pandemic set off a global recession by severely reducing economic production across the world causing losses in the trillions (Bachman, 2020). Individuals and/or countries were quarantined for a minimum of 
two weeks causing fear across the world for a more than a year now. Recently, vaccines have been administered to halt the virus and its negative effects on life and economic growth.

The purpose of this study is to test the semi-strong form market efficiency theory by examining the effect of the March 11, 2020, WHO global pandemic announcement on the risk adjusted stock price returns of a sample of healthcare firms using the standard risk adjusted event study methodology in the finance literature.

\section{LITERATURE REVIEW}

Fama $(1970,1976)$ defined market efficiency in three forms: weak-form, semi-strong-form, and strongform. Weak-form efficiency deals with the notion that no investor can earn an above normal, economic return by developing trading rules based on past price or return information. Numerous studies (Fama, 1965; Alexander, 1961; Fama and Blume, 1966; Granger and Morgenstern, 1970) support the random walk theory in support of weak form efficiency. If the market is weak form efficient, then stock price reacts so fast to all past information that no investor can earn an above normal risk adjusted return (i.e., higher than the market or the return on the S\&P 500 index) by acting on this type of information. For example, if an investor reviews a public quarterly report, and buys the firm's stock after discovering the firm had higher than expected earnings for the quarter and then stock price does not rise, the market is said to be efficient with respect to past information and is weak form efficient.

Semi-strong-form market efficiency states that no investor can earn an above normal, risk adjusted return based on any publicly available information. Tests of semi-strong form efficiency (Fama, Fisher, Jensen, and Roll, 1969; Ball and Brown, 1968; Aharony and Swary, 1980; Joy, Litzenberger, and McEnally, 1977; Watts, 1978; Patell and Wolfson 1979; Scholes, 1972; Kraus and Stoll, 1972; Mikkelson and Partch, 1985; Dann, Mayers, and Raab, 1977) document the claim that no investor can earn an above normal risk adjusted return on publicly available information such as accounting statements, stock split announcements, dividend announcements, sale of stock announcements, repurchase of stock announcements, block trades, and earnings announcements. If the market is semi-strong form efficient, then stock price reacts so fast to all public information that no investor can earn an above normal risk adjusted return (i.e. higher than the market or the return on the S\&P 500 index) by acting on this type of information. Public announcements of stock splits, repurchases, and dividend increases are examples of public information. If one buys the stock on the announcement and still does not make an above normal risk adjusted return, the market is semistrong form efficient. Tung \& Marsden (1998) provided a controlled environment and performed trading behavior tests which resulted in a positive relationship between information quality and market trading profits in support of the existence of semi-strong form efficiency within markets.

Strong-form efficiency theory suggests that no investor can earn an above normal risk adjusted return using any information, public or private. Studies on the validity of strong form efficiency offer mixed results (Jaffe, 1974; Finnerty, 1976; Givoly and Palmon, 1985; Friend, Blume, and Crockett, 1970; Jensen, 1968). If the market is strong form efficient, then stock prices react so fast to all information (public and private) that no investor can earn an above normal risk adjusted return (i.e. higher than the market or the return on the S\&P 500 index) by acting on this type of information. In this case, the market reacts to an event within the confines of the firm even before it is publicly announced. For this to occur, investors must act on insider information, which is illegal. If an investor is to buy the stock on the event of based on inside information, and still does not make an above normal risk adjusted return, the market is strong form efficient.

\section{Market Efficiency and Investment Analysis Fees}

This study tests the semi-strong market efficiency theory by using the standard event study methodology in the finance literature (Bacon, 2008, 2017, and 2020). If the market is semi-strong form efficient, then two popular methods of stock valuation are rendered useless resulting in a significant implication of this study's findings. Investors pay analysts who use these valuation models billions of dollars annually for investment advice and guidance. But if the market is efficient, these investors are wasting billions of dollars on useless investment advice. Efforts to determine the "right" value of stock are 
useless if the market is semi-strong form efficient since the "right" price is the market price that instantly impounds all available and relevant information (Bacon, 2008, 2017, 2018, and 2020).

\section{Stock Analysis Valuation Models}

The first popular method in the finance investment literature called into question by the efficient market hypothesis is technical stock analysis. Technical analysis is, in essence, the recording of the actual history of trading for one stock or a group of equities and deducing the future trend from this historical analysis. Technical analysts identify buy and sell points by analyzing past price movement with charts. Often called chartists, they closely examine the effect on stock price of supply and demand, popular opinions, moods, and blind necessities. Using these factors continually, technical analysis disregards the minor fluctuation in the market and identifies how stock prices tend to move in trends in the long run. Finally, changes in trends are determined by shifts in supply and demand relationships and can be detected sooner or later in the market (Levy, 1966). Critics contend that the past behavior of the stock market may not be indicative of future behavior and that the market moves in a random pattern. The market reacts to information, and since information arrives randomly, the market responds in a similar fashion. Also, multiple interpretations could be made by looking at the chart of past stock price movements. These critics also argue that if technical analysis were continually successful, an influx of technical traders will neutralize whatever profit potential exists (Levy, 1966).

The other stock popular valuation model used by analysts to determine market value is fundamental stock analysis. Fundamental stock analysis assumes that each security has an intrinsic value, which is the present value of expected future cash flows of the firm. Therefore, value and future cash flow depend upon the firm's earning potential, economic variables, and financial factors that cause actual market prices to move toward intrinsic values (Levy, 1966). If the fundamental intrinsic value is below the market value, the analyst recommends a sell signal and the opposite for a buy signal when the intrinsic value is above the market value. Critics of fundamental analysis contend that the market reacts so quickly to information that it is impossible to maximize profit since the investor is forced to wait for information to be publicly available. This information comprises statistics on sales, orders, earnings, and dividend announcements. Not only is this information hard to collect but it is also costly and not always reliable (Bacon, 2008, 2017, 2018, and 2020). A fundamental analyst may find himself heavily invested in a security for a considerable length of time before the market support develops (Levy, 1966).

\section{Semi-Strong Form Efficiency}

Finally, if the market is semi-strong form efficient, investors are wasting billions of dollars on technical and fundamental analyst fees for worthless advice. This study tests the semi-strong form efficient market hypothesis which claims that all stock prices reflect public information making it impossible to earn an abnormal risk adjusted return by acting or investing on public information, thus rendering technical and fundamental stock analysis useless. This information includes historical stock prices and published accounting statements of a firm (Ross et. al., 2016). This study tested the semi-strong form efficient market hypothesis by examining the risk-adjusted returns of 10 firms' stock prices from thirty trading days before the March 11, 2020 WHO global pandemic announcement to thirty days after. Ross defines an efficient market response as an immediate stock price adjustment to new information. There is no tendency for subsequent increases and decreases (Ross et. al., 2016).

Regarding literature specific to pandemics and their effects on the efficiency of markets, there are few studies to be found. Barker \& Bacon (2015) found that the Ebola outbreak of 2014 had a significant negative impact on a sample of airline firms. They also found that the market was efficient in the semi-strong firm, showing declining returns roughly 15 days before the event date. Unlike Ebola in 2014, COVID-19 is a respiratory illness that is easy to contract from person to person resulting in far greater financial, economic, and humanitarian damage. 


\section{METHODOLOGY}

This study examines 10 healthcare companies that the COVID-19 pandemic could potentially impact. The purpose of this study was to test the semi-strong form efficient market hypothesis by examining the risk-adjusted returns of 10 firms' stock prices from thirty trading days before the March 11, 2020, WHO global pandemic announcement to thirty days after. The firms' stock price returns were analyzed against the S\&P 500 from 180 trading days before March 11, 2020, to 30 trading days after (June 21, 2019 - April 23, 2020). The following hypotheses were tested:

H10: The risk adjusted rate of return of the sample of healthcare firms is not significantly affected by this information on the event date identifies as the announcement date.

$\mathrm{H1}_{1}$ : The risk adjusted rate or return of the sample of healthcare firms is not significantly negatively affected by this information on the event date.

$H_{2}$ : The risk adjusted rate of return of the sample of healthcare firms is not significantly positively affected by information around the event date as defined by the event period.

$\boldsymbol{H}_{1}:$ The risk adjusted rate of return of the sample of healthcare firms is not significantly positively affected by information around the event date as defined by the event period.

Using the standard risk adjusted event study methodology in the finance literature, the stock market's response is tested to the event date of March 11, 2020, or the WHO global pandemic announcement. For this study, all of the stock return information for the sample of firms and the S\&P 500 over and before event period were collected from Yahoo! Finance This data included stock prices of the firms and S\&P 500 from 180 days before to 30 days after the event date.

The daily holding period returns of the companies $(R)$ and $S \& P 500\left(R_{m}\right)$ were calculated using the following formula:

Current Daily Return $=($ current day close price - previous day close price $) /$ previous day close price

Using the holding period returns, a regression analysis was performed for each sample firm with the actual daily return for each company as the dependent variable and regressing it on the corresponding S\&P 500 Index, the independent variable. The regression was performed over the pre-event period (day -180 to -31) to obtain the intercept, alpha, and the standardized coefficient, beta, for each firm. This regression analysis yielded the alpha and beta for each company over the pre-event period as shown in Table 1 .

\section{TABLE 1}

\section{ALPHA AND BETA FOR SAMPLED FIRMS}

\begin{tabular}{|c|c|c|}
\hline Ticker & Alpha & Beta \\
\hline CVS & 0.001093 & 0.846031 \\
\hline UNH & 0.001156 & 1.161639 \\
\hline MCK & 0.000613 & 0.967867 \\
\hline ABC & 0.000607 & 0.947664 \\
\hline CI & 0.001214 & 1.243417 \\
\hline CAH & 0.00103 & 0.91316 \\
\hline WBA & -0.00038 & 0.777588 \\
\hline ANTM & 0.000111 & 1.240209 \\
\hline JNJ & 0.000744 & 0.703115 \\
\hline CNC & 0.001582 & 1.172555 \\
\hline
\end{tabular}


To calculate the normal expected returns, the risk-adjusted method (market model) was used. The expected returns for each stock, for each day of the event period was calculated using the formula:

$\mathrm{E}(\mathrm{R})=$ Alpha + Beta $\left(\mathrm{R}_{\mathrm{m}}\right)$

Then, the excess return was calculated as:

$\mathrm{ER}=$ Actual Return $-\mathrm{E}(\mathrm{R})$

Average Excess Return was found for each day by averaging the Excess Returns for each firm on a given day as follows, where $\mathrm{N}$ is the number of sample firms:

$\mathrm{AER}=$ Sum of Excess Returns/N

In addition, cumulative AER was calculated by adding the AER for each day of the event period, days -30 to +30 . For the event period, graphs of AER and CAER were plotted to show their movement over time. Exhibits 1 and 2 below display the Average Excess Returns and the Cumulative Average Excess Returns plotted against time over the event period for the sample of firms.

\section{QUANTITATIVE TESTS \& RESULTS}

Did the market react to the March 11, 2020, WHO global pandemic announcement? Were the riskadjusted stock price returns of the sample of firms significantly positively affected? If there was a significant reaction to the event, it would be expected that a substantial difference between the Actual Average Daily Returns (Day -30 to Day +30) and the Expected Average Daily Returns (Day -30 to +30 ) should be observed. If a significant risk adjusted difference is observed, then the evidence supports the alternative hypotheses that the global pandemic announcement caused a significant increase in stock prices returns. In order to test for a significant difference between the Actual Average Daily Returns and the Expected Average Daily Returns, a paired sample t-test was conducted and found a significant difference at a 5\% level between actual and expected risk adjusted returns of the sample of firms. The result of these test supports the alternative hypotheses $\mathrm{H}_{1}$ and $\mathrm{H} 2_{1}$ and concludes that the risk adjusted return of the stock price of the sample firms is indeed significantly positively affected around and on the event date.

It is also important to determine how fast the market reacted to the March 11, 2020, WHO global pandemic announcement event to assess the level of efficiency of the market response. Basically, did the market display weak, semi-strong, or strong form market efficiency? Specifically, are the Average Excess Returns (AERs) and the Cumulative Average Excess Returns (CAERs) for the samples of stocks significantly different than zero. T-tests of AER and CAER indicate a difference at the 5\% significance level. Observation of AER and CAER over the event period for Exhibits 1 and 2 shows a significant positive reaction of the risk adjusted returns of the stock prices of the sample prior to the event date.

When analyzing the CAER over the event period in Exhibit 2 below, the goal is to determine how fast the market reacted to the event. According to Exhibit 2, there is an increase from day -24 to day -12 and again from day -9 to day 0 , then returns leveled off. Possibly the observed positive reaction prior to the global pandemic announcement surfaced as a result of the increasing number of positive COVID-19 cases being reported in the international news. Consistent with market efficiency and behavioral finance theories (Fama, 1997), we observe a positive overreaction from day 0 to day +4 followed by a negative overreaction from day +4 to day +10 , then another positive overreaction and a return to equilibrium by day +30 .

Therefore, evidence shows that the market had already imbedded the global pandemic announcement information into the stock prices of the sample companies prior to the event date of March 11, 2020, thus supporting semi-strong form efficiency. Since the market already responded prior to the event date, no investor could earn an above normal risk adjusted rate of return on the event date. 
FIGURE 1

\section{AVERAGE EXCESS RETURNS PER DAY SURROUNDING THE ANNOUNCEMENT}

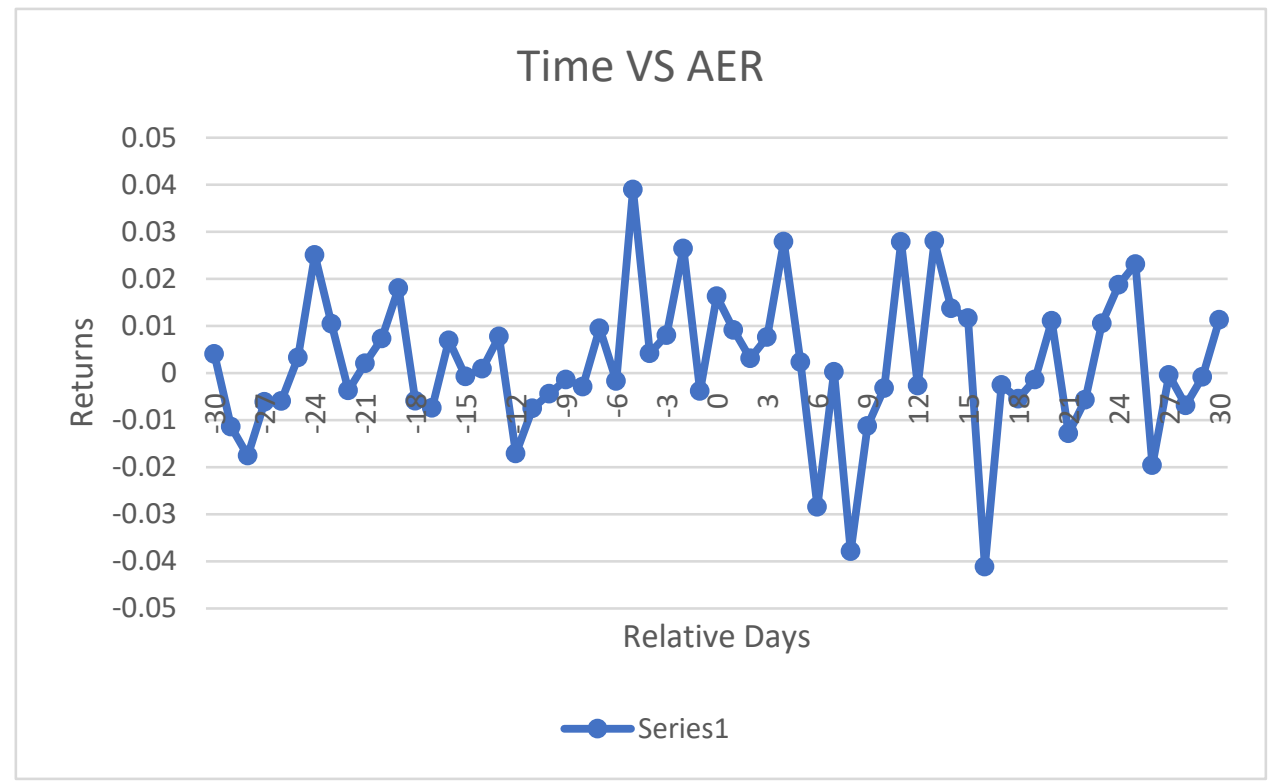

FIGURE 2

CUMULATIVE AVERAGE EXCESS RETURNS PER DAY SURROUNDING THE ANNOUNCEMENT

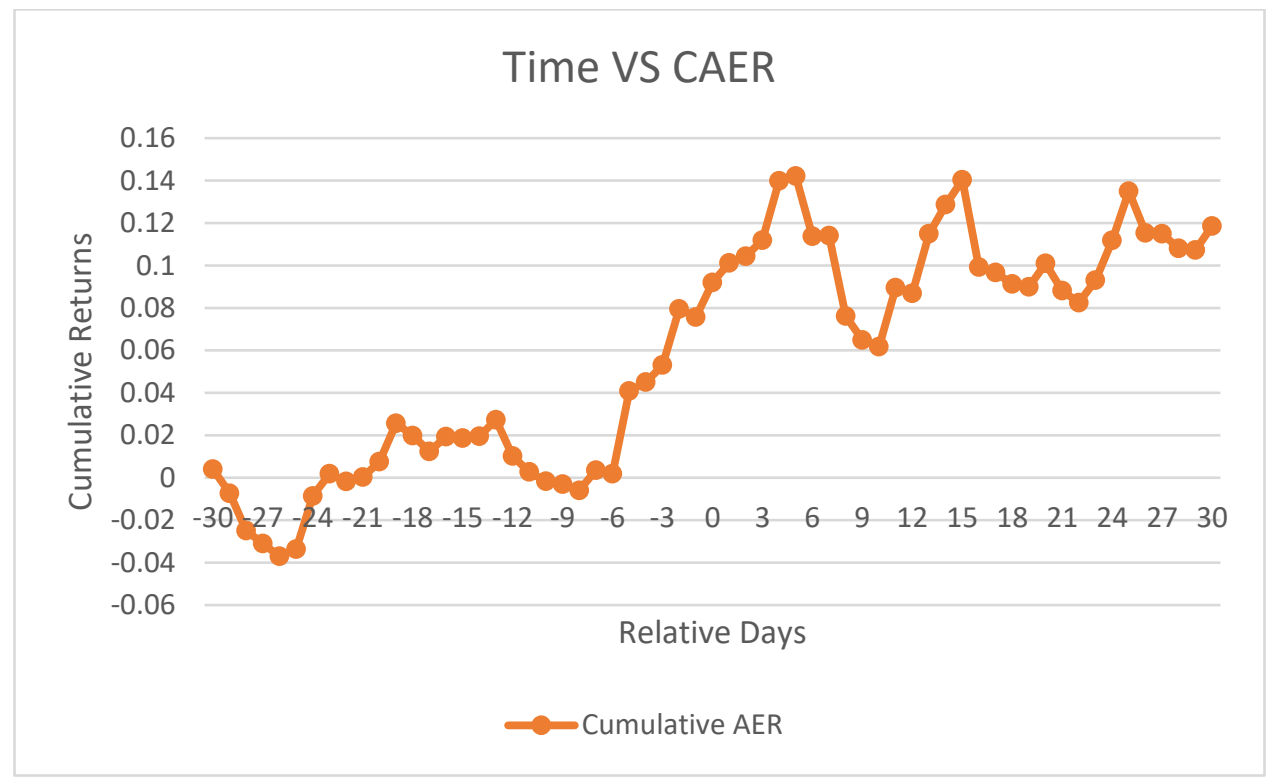

\section{CONCLUSION}

The World Health Organization (WHO) on Wednesday March 11, 2020, declared the rapidly spreading coronavirus outbreak a global pandemic. The purpose of this study is to examine the pandemic announcement to test for semi-strong form market efficiency. Will returns in the healthcare industry show excess gains in the event period of the COVID-19 announcement? While we can infer a link between pandemics, epidemics, outbreaks and the market, this link has not been heavily studied. In the efficient 
market theory, Eugene Fama proposes that in semi-strong form market efficiency all public information is factored into the market so fast that no investor can achieve an above normal return when adjusted for risk. To study this relationship, data for the S\&P 500 and 10 health care firms were collected for the event period surrounding the announcement of the COVID-19 pandemic. Using the standard event study methodology from the finance literature, this study tests the global pandemic announcement for semi-strong form market efficiency. Evidence here supports the expected positive signal associated with the sample of health care firms in reaction to the announcement of the pandemic. Likewise, the study results support the semi-strong form efficient market hypothesis and suggest the possibility of trading on this information up to 24 days prior to the announcement. Consistent with market efficiency and behavioral finance theories (Fama,1997), we observe a positive overreaction after the announcement from day 0 to day +4 followed by a gradual return to equilibrium by day +30 .

\section{REFERENCES}

Aharony, J., \& Swary, I. (1980, March). Quarterly Dividend and Earning Announcements and Stockholders' Returns: An Empirical Analysis. Journal of Finance, pp. 1-12.

Alexander, S. (1961, May). Price Movements in Speculative Markets: Trends or Random Walks. Industrial Management Review, pp. 7-26.

Bachman, D. (2020). The Economic Impact of COVID-19 (Novel Coronavirus). Retrieved from ww2.deloitte.com/us/en/insights/economy/covid-19/economic-impact-covid-19.html

Bacon, F.W., \& Cannon, C.C. (2018). Brexit Announcement: A Test of Market Efficiency. Journal of Applied Business and Economics, 20(8), 19-25.

Bacon, F.W., \& Gobran, P. (2017). Presidential elections and industry stock returns: A test of market efficiency. Journal of Business and Behavioral Sciences, 29(2), 21-31.

Bacon, F.W., \& Greis, J. (2008). Stock split announcements: A test of market efficiency. Journal of Business and Behavioral Sciences, 18(1), 18-27.

Bacon, F.W., \& Hutchinson, J.A. (2020). Corporate Sponsorship of the 2008, 2012, and 2016 Summer Olympics: A Test of Market Efficiency. Journal of Applied Business and Economics, 22(10), $13-$ 25.

Bacon, F.W., \& Pichardo, C. (2009). The Lehman Brother's bankruptcy: A test of market efficiency. Proceedings of the Allied Academies, 14(1), 43-48. International, USA.

Bacon, F.W., \& Spradlin, K.M. (2019). Forward and Reverse Stock Splits: A Test of Market Efficiency. Journal of Applied Business and Economics, 21(5), 18-28.

Baim, D.V., Goukasian, L., \& Misch, M.B. (2016). Olympic Sponsorships, Stock Prices, and Trading Activity. International Journal of Sport and Finance, 10(2) 175-195.

Ball, R., \& Brown, P. (1968, Autumn). An Empirical Evaluation of Accounting Income Numbers. Journal of Accounting Research, pp. 159-178.

Barker, L., \& Bacon, F. (2015). The Ebola Outbreak: A Test of Market Efficiency. Allied Academies International Conference: Proceedings of the Academy of Accounting \& Financial Studies (AAFS), 20(1), 2-6.

Beaver, W. (1981). Market Efficiency. The Accounting Review, 56(1), 23-37.

Dann, L., Mayers, D., \& Raab, R. (1977, January). Trading Rules, Large Blocks and the Speed of Adjustment. Journal of Financial Economics, pp. 3-22.

Fama, E.F. (1965). The Behavior of Stock Market Prices. The Journal of Business, 38(1), 34-105.

Fama, E.F., Fisher, L., Jensen, M., \& Roll, R. (1969, February). The Adjustment of Stock Prices to New Information. International Economic Review, 10(1), 1-21.

Fama, E.F., \& Blume, M.E. (1966). Filter Rules and Stock-Market Trading. The Journal of Business, $39(1), 226-241$.

Fama, E.F. (1970). Efficient Capital Markets: A Review of Theory and Empirical Work. The Journal of Finance, 25(2), 383-417. 
Fama, E.F. (1997). Market Efficiency, Long-Term Returns, and Behavioral Finance. Journal of Financial Economics, 49, 283-306.

Finnerty, J. (1976). Insiders and Market Efficiency. The Journal of Finance, 31(4), 1141-1148.

Friend, I., Blume, M., \& Crockett, J. (1970). Mutual Funds and Other Institutional Investors. McGrawHill, New York.

Givoly, D., \& Palmon, D. (1985, January). Insider Trading and the Exploitation of Inside Information: Some Empirical Evidence. Journal of Business, pp. 69-87.

Granger, C.W.J., \& Morgenstern, O. (1970). Predictability of Stock Market Prices. Heath Lexington Books, Lexington, Mass.

Jaffe, J. (1974, Spring). The Effect of Regulation Changes on Insider Trading. Bell Journal of Economics and Management Science, pp. 93-121.

Jensen, M. (1968, May). The Performance of Mutual Funds in the Period 1945-64. Journal of Finance, pp. $389-416$.

Jensen, M.C. (1978). Some Anomalous Evidence Regarding Market Efficiency. Journal of Financial Economics, 6(2/3), 95-101.

Joy, M., Litzenberger, R., \& McEnally, R. (1977, Autumn). The Adjustment of Stock Prices to Announcements of Unanticipated Changes in Quarterly Earnings. Journal of Accounting Research, pp. 207-225.

Kraus, A., \& Stoll, H.R. (1972, June). Price Impacts of Block Trading on the New York Stock Exchange. Journal of Finance, pp. 569-588.

Levy, R. (1966). Conceptual Foundations of Technical Analysis. Financial Analysts Journal, 22(4), 8389.

Levy, R.A. (1967). The Theory of Random Walks: A survey of Findings. American Economist, 11(2), $34-48$.

Mcnichols, M., \& Dravid, A. (1990). Stock Dividends, Stock Splits, and Signaling. The Journal of Finance, 45(3), 857-879.

Mikkelson, W., \& Partch, M. (1985, June). Stock Price Effects and the Costs of Secondary Distribution. Journal of Financial Economics, pp. 165-194.

Patell, J., \& Wolfson, M. (1979, August). Anticipated Information Releases Reflected in Call Option Prices. Journal of Accounting and Economics, pp. 117-140.

Ross, S.A., Westerfield, R., Jaffe J., \& Jordan, B. (2016). Corporate Finance (11th ed.). McGraw-Hill Education.

Rozeff, M.S., \& Zaman, Z.A. (1988). Market Efficiency and Insider Trading: New Evidence. The Journal of Business, 61(1), 25-44.

Tung, Y.A., \& Marsden, J.R. (1998). Test of Market Efficiences Using Experimental Electronic Markets. Journal of Business Research, 41(2), 145-154.

Watts, R. (1978, June/September). Systematic 'Abnormal' Returns after Quarterly Earnings Announcements. Journal of Financial Economics, pp. 127-150.

WHO. (2020). Coronavirus Disease (COVID-19). Retrieved from www.who.int/emergencies/diseases/novel-coronavirus-2019 